\title{
Agility and Speed Standards for Student Teenager Wrestlers
}

\author{
Isik Bayraktar \\ The Ministry of Youth and Sport, General Directorate of Sport, Turkey
}

Copyright $(2017$ by authors, all rights reserved. Authors agree that this article remains permanently open access under the terms of the Creative Commons Attribution License 4.0 International License

\begin{abstract}
The processes of talent identification and development provide serious advantages to success of athletes. The interpretation of the current situation in the process of the athletes' education gets more worth through the use of objective assessment, in other words using norm values. The observation of the talent by norms is important for each sport event like it is for wrestling. The purpose of this study is to determinate the normative values of speed and agility ability for student wrestlers. The research group is a group of 480 male student wrestlers between 13-16 years old. The linear speed ability of the group is identified for 13 year olds is $3,576 \pm 0,239 \mathrm{sec}$., for 14 years is $3,422 \pm 0,197 \mathrm{sec}$., for 15 years is $3,316 \pm 0,195 \mathrm{sec}$. and for 16 years is $3,22 \pm 0,166$ sec. Agility ability of the students is found out for 13 years is $5,701 \pm 0,399 \mathrm{sec}$., for 14 years is $5,487 \pm 0,391 \mathrm{sec}$, for 15 years is $5,399 \pm 0,439 \mathrm{sec}$. and for 16 years is $5,303 \pm 0,346 \mathrm{sec}$. Coaches will have the opportunity to determine objectively the level of their athletes according to their ages because of this study is standardizing speed and agility abilities of student wrestlers as $10 \%$ of slices.
\end{abstract}

Keywords Speed, Agility, Normative, Teenager, Wrestler

\section{Introduction}

Talent identification and talent development plays an important role in search of excellence (Vaeyens, Lenoir, Williams, \& Philippaerts, 2008).The success of practice in the process depends on objective assessments. The interpretation of athletic test results improves thanks to norm values.

Norms are values showing relationship of individual result with general population (Adams, 1998). In the sports researches, numbers of subject taken for norm studies are alterable from 50 to 10 thousand. It loses reality when numbers of athletes are less than the required numbers to obtain norms. Therefore large number makes it easier to use the necessary logarithm (Bös, 2003).

It is known that the speed ability of boys improves between the age of 5-18, and agility performance is developing till the age of 18 , especially between 5-8 years old (Malina, Bouchard, \& O., 2004). The importance of speed and agility ability in many sport events is undeniable (Hoffman, 2006). In wrestling, which exist since thousands of years (Yockey, 2006), speed and agility are important component for success like the other motoric features (Mirzaei, Curby, Rahmani-Nia, \& Moghadasi, 2009). Besides that, if wrestlers have high level of agility and speed ability, they can perform their technique more quickly than others (Mirzaei, Rahmani-Nia, Curby, Barbas, \& Lofti, 2011).

It is considered that there is a strong relationship between speed and agility ability performance but the correlation has a low level according to result of scientific studies (Bayraktar, 2013; Buttifant, Graham, \& Cross, 1999; Markovic, 2007; Sheppard \& Young, 2006; Young, Hawken, McDonald, \& others, 1996). Although speed and agility exercises seem to be like running activity, it is known that they cannot take place instead of each other inner training (Bayraktar, 2013).

Tests of linear sprinting and agility were usually used in field tests in order to determinate sport performance (Hoffman, 2006; Vescovi \& Mcguigan, 2008). However, there are few normative data for the use of comparison on different athlete populations (Hoffman, 2006). About wrestling, there were not found any norms of speed $(20 \mathrm{~m}$. sprint test) and agility (pro-agility test) ability in sport researches. Created norms will be effective in the talent identification and development stages for not only wrestling, but also all sport events.

Wrestling which is Turkish traditional sport has a huge proportion of Turkish Olympic achievements. Wrestlers gained 66 percent (63/95 medals) of total medals in Turkish Olympic history until now. Turkish wrestlers have 29 gold medals in Olympic Games including Rio 2016. They have almost taken gold medal each Olympic game (TMOK, 2016). The purpose of this study is to determinate the normative values of speed and agility ability for student wrestlers who live in Turkey which is a prominent country for the world wrestling. In this way, coaches can objectively assess their athletes' level of speed and agility ability. 


\section{Method}

The research group is a group of 480 male student wrestlers between 13-16 years old. Mean and standard deviation (SD) were shown in the Table 1. It shows body weight $(\mathrm{BW})$, height $(\mathrm{BH})$, body mass index (BMI), 20 meter linear speed $(20 \mathrm{mS})$ and pro-agility ability of the wrestlers. The study was performed in accordance with the Declaration of Helsinki.

Table 1. Age, BM, BH, BMI, $20 \mathrm{mS}$ and pro-agility values of the study group

\begin{tabular}{|c|c|c|c|}
\hline & $\mathbf{n}$ & Mean & SD \\
\hline Age (year) & \multirow{6}{*}{480} & 14,37 & 0,95 \\
\hline BW (kg) & & 54,13 & 13,26 \\
\hline $\mathbf{B W}(\mathrm{cm})$ & & 159,36 & 9,64 \\
\hline $\mathbf{B M I}\left(\mathrm{kg} / \mathrm{m}^{2}\right)$ & & 21,04 & 3,31 \\
\hline $20 \mathrm{mS}(\mathrm{s})$ & & 3,394 & 0,231 \\
\hline Pro-agility (s) & & 5,468 & 0,422 \\
\hline
\end{tabular}

\subsection{Gathering of the Data}

It was utilized photocell device for speed and agility measurement (SmartSpeed-Fusion Sport, Australia). Body height of subjects has been measured by portable stadiometer which has sensitivity level $0.1 \mathrm{~cm}$ (Charder HM200P). Body weight was assessed using an electronic weight scale (Tanita HD376).

Pro-agility Test: For the pro-agility test, which is also known as the 20 yard running test, pins were set 5 yards $(4,57 \mathrm{~m})$ on the left and on the right side (Figure 1). A timing gate (Smart Speed-Fusion Sport, Australia) was placed at the starting line. This way repeating passes were recorded. Before the test starts the athletes takes position. When the athlete is ready she is first touching the right pin, then the left pin, passes the starting line and finishes the test. For each athlete the total time was recorded.

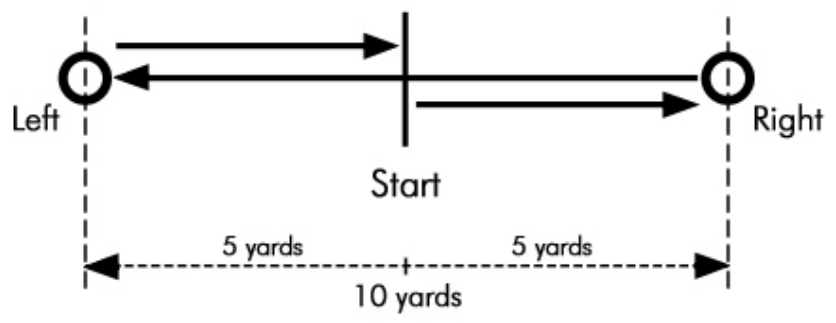

Figure 1. Schematic illustration of the pro agility test

In order to determine the subjects' sprint ability running tests of 20 meter were performed. All results were recorded using photoelectric timing gates (Smartspeed, Fusionsport, Australia).

\subsection{Analysis of Data}

For the statistical procedure SPSS 17.0 pocket program was applied. The standard statistical parameters (mean, SD) were calculated for each test. Arithmetic mean (x), standard deviation (SD) were shown in the tables as $10 \%$ of slices. In use of the norms in the tables; the following grading accepted as Canada criterion was taken as criterion (Adams, 1998).

It was calculated as follows;

- Scores below 20\%; "weak" or "low"

- Scores between 21-40\%; "below average"

- Scores between 41-60\%; "average"

- Scores between 61-80\%; "above average"

- Scores above $81 \%$, "very high" or "perfect"

\section{Results}

In this section, the research group's mean and standard deviation values of BW, BH, BMI measurements and norm values for 20 meter speed test and pro-agility ability were shown as tables according to their ages.

The research group's mean and standard deviation values of BW, BH, BMI according to their ages is given in table 2 .

Table 2. BW, BH and BMI values of the research group according to their ages

\begin{tabular}{|c|c|c|c|c|c|}
\hline \multicolumn{2}{|c|}{ Category } & 13A & 14A & 15A & 16A \\
\hline \multicolumn{2}{|c|}{$\mathrm{n}$} & 100 & 165 & 154 & 61 \\
\hline \multirow{2}{*}{$\begin{array}{c}\text { BW } \\
(\mathrm{kg})\end{array}$} & Mean & 47,21 & 52,06 & 57,31 & 63,10 \\
\cline { 2 - 6 } & SD & 12,37 & 12,98 & 11,84 & 11,60 \\
\hline \multirow{2}{*}{$\begin{array}{c}\text { BH } \\
(\mathrm{cm})\end{array}$} & Mean & 152,49 & 157,37 & 162,90 & 166,92 \\
\cline { 2 - 6 } & SD & 8,38 & 9,00 & 7,90 & 8,15 \\
\hline \multirow{2}{*}{$\begin{array}{c}\text { BMI } \\
\left(\mathrm{kg} / \mathrm{m}^{2}\right)\end{array}$} & Mean & 20,09 & 20,74 & 21,40 & 22,51 \\
\cline { 2 - 6 } & SD & 3,47 & 3,42 & 2,97 & 2,94 \\
\hline
\end{tabular}

*A: Age

When examining table 3 , the values of $\mathrm{BW}, \mathrm{BH}, \mathrm{BMI}$ rises parallel with the age increase.

Table 3. Normative values relating to wrestlers' parameters of pro-agility test

\begin{tabular}{|c|c|c|c|c|c|}
\hline Category & $\mathbf{\%}$ & $\mathbf{1 3 A}$ & $\mathbf{1 4 A}$ & $\mathbf{1 5 A}$ & $\mathbf{1 6 A}$ \\
\hline \multirow{2}{*}{ Low } & 10 & 6,238 & 5,992 & 5,927 & 5,846 \\
\cline { 2 - 6 } & 20 & 6,016 & 5,785 & 5,686 & 5,565 \\
\hline \multirow{3}{*}{ Below Average } & 30 & 5,861 & 5,677 & 5,519 & 5,439 \\
\cline { 2 - 6 } & 40 & 5,787 & 5,492 & 5,417 & 5,296 \\
\hline \multirow{2}{*}{ Average } & 50 & 5,693 & 5,415 & 5,347 & 5,258 \\
\cline { 2 - 6 } & 60 & 5,548 & 5,338 & 5,274 & 5,154 \\
\hline \multirow{2}{*}{ Above Average } & 70 & 5,456 & 5,266 & 5,154 & 5,090 \\
\cline { 2 - 6 } & 80 & 5,360 & 5,172 & 5,043 & 5,003 \\
\hline \multirow{2}{*}{ Very High } & 90 & 5,258 & 5,040 & 4,889 & 4,907 \\
\cline { 2 - 6 } & 99 & 4,956 & 4,746 & 4,607 & 4,641 \\
\hline Mean & 5,701 & 5,487 & 5,376 & 5,303 \\
\hline SD & 0,399 & 0,391 & 0,397 & 0,346 \\
\hline Skewness & 0,615 & 0,808 & 0,551 & 0,700 \\
\hline \multirow{2}{*}{ Kurtosis } & 0,589 & 0,631 & 0,234 & 0,001 \\
\hline
\end{tabular}

*A: Age 
The results of the normative values relating to athletes' parameters of pro-agility values of wrestlers' analysis are shown in table 3.

When examining table 3 , the values of pro-agility performance rises parallel with the age increase. When examining the coefficients of skewness, the value limited between +1 and -1 of the skewness coefficient can be interpreted as the range near normal values. For this reason, it is seen that the age groups of the athletes show a range near normal range. When examining the coefficients of kurtosis according to the normal range, it is determined that the findings belonging to the age groups generally show more compressed range.

The results of the normative values relating to athletes' parameters of 20 meter speed values of wrestlers' analysis are shown in table 4.

Table 4. Normative values relating to wrestlers' parameters of $20 \mathrm{mS}$ test

\begin{tabular}{|c|c|c|c|c|c|}
\hline Category & $\mathbf{\%}$ & $\mathbf{1 3 A}$ & $\mathbf{1 4 A}$ & $\mathbf{1 5 A}$ & $\mathbf{1 6 A}$ \\
\hline \multirow{2}{*}{ Low } & 10 & 3,908 & 3,670 & 3,592 & 3,455 \\
\cline { 2 - 6 } & 20 & 3,800 & 3,589 & 3,480 & 3,371 \\
\hline \multirow{2}{*}{ Below Average } & 30 & 3,694 & 3,505 & 3,401 & 3,310 \\
\cline { 2 - 6 } & 40 & 3,621 & 3,457 & 3,353 & 3,250 \\
\hline \multirow{2}{*}{ Average } & 50 & 3,533 & 3,420 & 3,323 & 3,204 \\
\cline { 2 - 6 } & 60 & 3,479 & 3,366 & 3,250 & 3,173 \\
\hline \multirow{2}{*}{ Above Average } & 70 & 3,420 & 3,307 & 3,195 & 3,107 \\
\cline { 2 - 6 } & 80 & 3,353 & 3,263 & 3,146 & 3,075 \\
\hline \multirow{2}{*}{ Very High } & 90 & 3,290 & 3,163 & 3,062 & 3,016 \\
\cline { 2 - 6 } & 99 & 3,154 & 2,992 & 2,924 & 2,918 \\
\hline Mean & 3,576 & 3,422 & 3,316 & 3,220 \\
\hline SD & 0,239 & 0,197 & 0,195 & 0,166 \\
\hline Skewness & 0,562 & 0,490 & 0,392 & 0,327 \\
\hline Kurtosis & $-0,054$ & 0,764 & 0,091 & $-0,414$ \\
\hline
\end{tabular}

*A: Age

When examining table 4 , the values of 20 meter speed performance rises parallel with the age increase. When examining the coefficients of skewness, the value limited between +1 and -1 of the skewness coefficient can be interpreted as the range near normal values. For this reason, it is seen that the age groups of the athletes show a range near normal range. When examining the coefficients of kurtosis according to the normal range, it is determined that the findings belonging to the age groups generally show more compressed range.

\section{Discussion}

In the process of talent identification and development it is necessary to create estimation models in each sport event according to gender and age group. While setting the sport talent evaluation standards the estimation of the athletes potential of challenge have to be defined as the special view of sports scientists and specialists according to sport event, gender and age group (Ko, Park, Yun, Lee, \& Shin, 2003).

In this context, normative values were created for obtained results of 20 meter speed and pro-agility tests in student male wrestler. There were found no study about norms of 20 meter speed and pro-agility tests in wrestling. That means, current study is the first of its kind.

Because wrestling is a high-intensity sport, explosive offensive and defensive maneuver define winner and looser during the match. The interval agility trainings are accepted as a high practicable conditional need (Dawes \& Roozen, 2012). Although inner wrestling researches, less count of agility tests have been found (Mirzaei, Curby, Barbas, \& Lotfi, 2011; Mirzaei et al., 2009; Mirzaei, Curby, \& Rahmani-Nia, 2011; Mirzaei, Rahmani-Nia, et al., 2011; Nikooie, Cheraghi, \& Mohamadipour, 2015; Rahmani-Nia, Mirzaei, \& Nuri, 2007). There is no study found for pro-agility test in wrestlers throughout the sources.

Pro-agility findings of the study compared with same test in other sport events can give an idea about this age group. Further it can give an idea about the usage of the table. In the study of Wroble and Moxley (2001) with high school football players $(\mathrm{n}=57)$ according to pro-agility measurements the mean of 5,02 $\pm 0,24 \mathrm{sec}$. has been reached. In our studies this value for the mean of 16 year olds $(5,303 \pm 0,346 \mathrm{sec}$.) shows a higher performance. According to norm values it takes place as $90 \%$ for 14 year olds, and $80 \%$ for 15 and 16 year olds.

In the pro-agility norm values study according to the playing position of American Football players, the lowest mean of performance is $4,74 \pm 0,39 \mathrm{sec}$. For this research finding it is a perfect level $(\% 100)$. This difference can be explained with the fact, that the football players are high level athletes (NLF) (Hoffman, 2006).

In the research resources there are nearly no test about the $20 \mathrm{~m}$ speed run test for wrestlers. In a study for Polish young national wrestlers $(\mathrm{n}=107$; age $=18,46 \pm 1,11$ year) the mean value of $20 \mathrm{~m}$. speed run is reported as 2,66 $\pm 0,14 \mathrm{sec}$. (Baić, Sertić, \& Starosta, 2007). When we asses this mean with the findings of our study it is obviously that it is a performance which is even higher than the perfect level of 16 year olds level.

In another study which investigates some features of a 12 week training applied on wrestlers $(n=20)$ the pretest finding is $3.76 \pm .033 \mathrm{~s}$., the last test finding is $3.71 \pm 0.31 \mathrm{~s}$. As this is compared with the norms for 13 year olds both results take place in a "low" level segment of $20 \%$.

Let's evaluate the $20 \mathrm{~m}$ speed run values with another sport event (14 year old male basketball player) than wrestling just to achieve a sample. In the research with basketball players the mean value of the $20 \mathrm{~m}$. speed run test is measured as 3,54 $\pm 0,25 \mathrm{sec}$. (Jakovljevic, Karalejic, Pajic, Macura, \& Erculj, 2012). This value compared to our 20 meter norms for 14 year olds it is obviously that it is in a section of "under mean".

In another study with wrestlers in Turkey where a group of 15-17 year old athletes $(n=30)$ were investigated according 
to the seasonal variations of their performance, the $20 \mathrm{~m}$ speed run test has been used. In this study during the season four different measurements have been done where the best $20 \mathrm{~m}$. speed run performance is reported as 3,55 $\pm 0,25 \mathrm{sec}$. (Cicioglu, Kürkçü, Eroglu, \& Yüksek, 2007). When these findings were compared with each other it is obviously that for 15 and 16 year olds it has a week level of $20 \%$.

As a result the abilities of speed and agility which are evaluated as the performance components of the wrestling sport event can be chased through objectively criterions thanks to norms. The achieved norms of this study can be used easily by wrestling coaches of 13-16 year old athletes. The use and development of sport specific norm values is important for the long term athletic development.

\section{REFERENCES}

[1] Adams, G. (1998). Exercise Physiology Laboratory Manual (3rd ed.). WCB/MacGraw-Hill Publishers.

[2] Baić, M., Sertić, H., \& Starosta, W. (2007). Differences in physical fitness levels between the classical and the free style wrestlers. Kineziologija, 39(2), 142-149.

[3] Bayraktar, I. (2013). Relationships Between Agility, Speed, Reaction and Vertical Jump Ability Of Elite Boxers. Academic Sight International Refereed Online Journal of Social Sciences, (35), 1-8.

[4] Bös, K. (2003). Motorische Leistungsfahigkeit von Kindern und Jugendlichen. Schorndorf. Germany: Verlag Karl Hoffmann.

[5] Buttifant, D., Graham, K., \& Cross, K. (1999). Agility and speed measurement in soccer players are two different performance parameters. In Fourth World Congress of Science and Football (p. 57).

[6] Cicioglu, I., Kürkçü, R., Eroglu, H., \& Yüksek, S. (2007). Seasonal Changes on Some Physical And Physiological Characteristics of Wrestlers Aged 15-17 Years. Spormetre Beden Egitimi ve Spor Bilimleri Dergisi, 4, 151-156.

[7] Dawes, J., \& Roozen, M. (Eds.). (2012). Developing agility and quickness. Human Kinetics.

[8] Hoffman, J. (2006). Norms for fitness, performance, and health. Champaign, IL: Human Kinetics, c2006. Retrieved from

http://search.ebscohost.com/login.aspx?direct=true \&db=cat0 0818a\&AN=ank.1078876\&lang=tr\&site=eds-live\&authtype $=$ ip,uid

[9] Jakovljevic, S. T., Karalejic, M. S., Pajic, Z. B., Macura, M. M., \& Erculj, F. F. (2012). Speed and agility of 12-and 14-year-old elite male basketball players. The Journal of Strength \& Conditioning Research, 26(9), 2453-2459.

[10] Ko, B. G., Park, D. H., Yun, S. W., Lee, J. G., \& Shin, S. Y. (2003). The Construction of Sports Talent Identification Models. International Journal of Applied Sports Sciences (IJASS), 15(2), 64-84.
[11] Malina, R. M., Bouchard, C., \& O., B.-O. (2004). Growth, maturation and physical activity (2nd edn.). Human Kinetics, Champaign, IL.

[12] Markovic, G. (2007). Poor relationship between strength and power qualities and agility performance. Journal of Sports Medicine and Physical Fitness, 47(3), 276.

[13] Mirzaei, B., Curby, D. G., Barbas, I., \& Lotfi, N. (2011). Anthropometric and physical fitness traits of four-time World Greco-Roman wrestling champion in relation to national norms: A case study. Journal of Human Sport and Exercise, 6(2), 406-413. http://doi.org/10.4100/jhse.2011.62.21

[14] Mirzaei, B., Curby, D. G., Rahmani-Nia, F., \& Moghadasi, M. (2009). Physiological profile of elite Iranian junior freestyle wrestlers. The Journal of Strength \& Conditioning Research, 23(8), 2339-2344.

[15] Mirzaei, B., Curby, D. G., \& Rahmani-Nia, L. N. (2011). The relationship between flexibility, speed and agility measures of successful wrestlers. Kinaithropomety. UK (Inpress).

[16] Mirzaei, B., Rahmani-Nia, F., Curby, D. G., Barbas, I., \& Lofti, N. (2011). Physical fitness measuring of cadet wrestler. International Journal of Wrestling and Science, 1(1), 63-66.

[17] Nikooie, R., Cheraghi, M., \& Mohamadipour, F. (2015). Physiological determinants of wrestling success in elite Iranian senior and junior Greco-Roman wrestlers. The Journal Of Sports Medicine And Physical Fitness. Retrieved from http://search.ebscohost.com/login.aspx?direct=true $\& \mathrm{db}=\mathrm{mdc}$ $\& A N=26632849 \&$ lang $=$ tr\&site $=$ ehost-live

[18] Rahmani-Nia, F., Mirzaei, B., \& Nuri, R. (2007). Physiological profile of elite Iranian junior Greco-Roman wrestlers. International Journal of Fitness, 3(2), 49-54. Retrieved from

http://search.ebscohost.com/login.aspx?direct=true $\& \mathrm{db}=\mathrm{s} 3 \mathrm{~h}$ $\& \mathrm{AN}=31371471 \&$ lang $=$ tr\&site $=$ ehost-live

[19] Sheppard, J. M., \& Young, W. B. (2006). Agility literature review: classifications, training and testing. Journal of Sports Sciences, 24(9), 919-32.

http://doi.org/10.1080/02640410500457109

[20] Vaeyens, R., Lenoir, M., Williams, a M., \& Philippaerts, R. M. (2008). Talent identification and development programmes in sport: current models and future directions. Sports Medicine (Auckland, N.Z.), 38(9), 703-14. Retrieved from http://www.ncbi.nlm.nih.gov/pubmed/18712939

[21] Wroble, R. R., \& Moxley, D. R. (2001). The effect of winter sports participation on high school football players: strength, power, agility, and body composition. Journal of Strength and Conditioning research/National Strength \& Conditioning Association, 15(1), 132-135.

[22] Yockey, J. (2006). Wrestling: An elementary approach. Teaching Elementary Physical Education, 17, 14-17.

[23] Young, W., Hawken, M., McDonald, L., \& others. (1996). Relationship between speed, agility and strength qualities in Australian Rules football. Strength Cond Coach, 4(4), 3-6. 